\title{
Anticancer Effect of Hypophyllanthin, Niranthin and Lintetralin From Phyllanthus amarus on HeLa Cells And NIH/3T3 Cells
}

\author{
Nur Affira Mohd Noor, Mohd Azlan Nafiah, Syed Ahmad Tajudin Tuan Johari, Muhammad Hafiz \\ Husna Hasnan, Siow-Ping Tan, Sook Yee Liew, Unang Supratman
}

\begin{abstract}
Phyllanthus amarus which is locally known as Dukung Anak was one of the herb used in traditional medicine and research of $P$. amarus in Malaysia was not widely reported. This present research has isolated three chemical compounds and its anticancer effect of this species has been determined. Three lignans namely hypophyllanthin was afforded from hexane crude while niranthin and lintetralin were afforded from ethanol crude. Anticancer test against HeLa cells and NIH/3T3 cells by MTT assays was tested for its anticancer effect. The result shows that hypophyllanthin was considered to possess an active anticancer effect on HeLa cells than NIH/3T3 cells compared to niranthin and lintetralin.
\end{abstract}

Index Terms: Anticancer, HeLa cells, Lignans, NIH/3T3 cells and Phyllanthus amarus

\section{INTRODUCTION}

Phyllanthus amarus belongs to the family of Euphorbiaceae. Euphorbiaceae is a large family of flowering plants with 300 genera and around 7,700 species that are distributed in all tropical regions of the world from Africa to Asia, South America and the West Indies. This plant grows well in moist, shady and sunny places. They can be monoecious or dioecious [1]- [4]. P. amarus is a small, erect and annual plant. It grows up to $10-60 \mathrm{~cm}$ tall with elliptic oblong to obvate, obtuse or apiculate at apex, obtuse or inequilateral at base leaves. The flowers have 5 white, yellow

Revised Manuscript Received on April 25, 2019.

Nur Affira Mohd Noor, Department of Chemistry, Faculty of Science and Mathematics, Universiti Pendidikan Sultan Idris, 35900 Tanjong Malim, Perak, Malaysia.

Mohd Azlan Nafiah, Department of Chemistry, Faculty of Science and Mathematics, Universiti Pendidikan Sultan Idris, 35900 Tanjong Malim, Perak, Malaysia

Syed Ahmad Tajudin Tuan Johari, Faculty of Bioresources and Food Industry, Universiti Sultan Zainal Abidin, Besut Campus, 22200 Besut, Kuala Terengganu, Malaysia.

Muhammad Hafiz Husna Hasnan, Department of Chemistry, Faculty of Science and Mathematics, Universiti Pendidikan Sultan Idris, 35900 Tanjong Malim, Perak, Malaysia.

Siow-Ping Tan, Department of Physical Science, Faculty of Applied Science, Tunku Abdul Rahman University College, 53300 Setapak, Kuala Lumpur, Malaysia.

Sook Yee Liew, Chemistry Division, Centre for Foundation Studies in Science, University of Malaya, 50603 Kuala Lumpur, Malaysia.

Unang Supratman, Central Laboratory, Universitas Padjadjaran, Jatinangor, Indonesia. or grey sepals, auxilliary with bisexual cymules and its capsules are $1.8 \mathrm{~mm}$ in diameter, oblate and rounded. The seeds are about $0.9 \mathrm{~mm}$ long, pale brown and triangular with transverse striations on the back [5]-[10].

P. amarus has been described in Ayurveda by Sanskrit name called Bhoomyaamalakee, Taamalakee and Bhoodhatree. It is also known as Bahupatra and Bhuiamla in Central and Southern India respectively which grows mostly on uncultivated land [11]. It is also known as Chanca piedra in Spanish which means stone breaker or shatter stone [12]. $P$. amarus is bitter, astringent, diuretic, stomachic, febrifuge and antiseptic. This plant is considered to be diuretic when boiled and can be used in treatment of diabetes, hepatitis, menstrual disorders and skin disorders [13]-[16]. It is also traditionally used in the treatment of jaundice, asthma, kidney problems, urinary bladder, female problems such as leucorrhoea and mammary abscess, tumor and chronic dysentery [17]. All parts of P. amarus have been studied and are found to contain various chemical compounds such as lignans, alkaloids, phenols, terpenoids, flavonoids, tannins and gallotanoids [18]-[19]. Phyllanthus lignans are reported to have a potential action as multidrug resistance reversing agent, hepatoprotective agent, antiviral agent [20]-[23].

However, $P$. amarus have not been widely investigated so far in Malaysia. This present study is to isolate chemical compounds from hexane and ethanol crude extract. This lead to isolation of compounds hypophyllanthin (1), niranthin (2), and lintetralin (3) and their structure are elucidated by NMR $\left({ }^{1} \mathrm{H},{ }^{13} \mathrm{C}\right.$ and DEPT, COSY, HMQC, and HMBC). All the spectroscopic data are similar with the previous reported literature values [24]-[25].

\section{MATERIALS AND METHODOLOGY}

\section{A. Plant Collection}

The sample of $P$. amarus was collected from Melor, Kelantan. The whole part of the plants was air dried at room temperature and then was kept in a light-resistant container at the Herbarium of Organic Lab, Chemistry Department, UPSI, Perak, Malaysia. 


\section{Anticancer Effect of Hypophyllanthin, Niranthin And Lintetralin From Phyllanthus amarus on HeLa Cells And NIH/3T3 Cells}

\section{B. Extraction and Isolation}

Dried $P$. amarus $(2.01 \mathrm{~kg})$ were ground into powder. It was continuously extracted with ethanol for 3 days and repeated for three times at room temperature and then it was filtered. The resulted ethanol crude extract $(95.8 \mathrm{~g})$ was then used to produce hexane, ethyl acetate and methanol crude extracts by using solvent-solvent partitioning method. All crude extracts were obtained by removing the solvent under reduced pressure and the yield was the dry weight of the extracts.

The hexane and ethanol crude extract were tested for the chemical constituent contents using TLC and spotting with sulphuric acid. Then the crude extracts were subjected to column chromatography over silica gel using mixtures of hexane, hexane/dichloromethane, dichloromethane and dichloromethane/methanol as eluents. All three compounds were obtained by recycling preparative high-performance liquid chromatography (HPLC). Compound 1 was obtained from hexane crude while compounds 2 and 3 were obtained from ethanol crude. The chromatographic separation was performed on a reverse-phase of JAIGEL-ODS-AP Liquid Chromatography (Japan). ODS-AP is a general reverse phase column, packed with highly pure silica gel bonded ODS and end-capped. The detection wavelength used was $230 \mathrm{~nm}$. Before the injection, the column was saturated with acetonitrile as mobile phase.

\section{Cell Line Culture}

Human cervical cancer HeLa and normal mouse fibroblast NIH/3T3 were obtained from American Type Culture Collection (ATCC, Manassas, VA, USA). Those cells were grown in media containing RPMI-1640 media (Gibco, USA), supplemented with $10 \%$ fetal bovine serum (Gibco, USA) and antibiotics $(10,000$ units $/ \mathrm{mL}$ penicillin, $10 \mathrm{mg} / \mathrm{mL}$ streptomycin and $0.025 \mathrm{mg} / \mathrm{mL}$ amphotericin B (Biological Industries, Israel) which then maintained in an incubator at $37^{\circ} \mathrm{C}$ and at $5 \% \mathrm{CO}_{2}$ in a humidified atmosphere. The semi confluent cells from these two adherent cells were treated with trypsin-like enzyme with phenol red (Gibco, USA) for 5 minutes and then were resuspended in medium with serum and transferred into 3 new flasks. After trypsinization, the cells were count and the cell viability was tested by trypan blue using a hemocytometer. Cell viability above $95 \%$ was used for this study.

\section{MTT Cytotoxicity Assay}

A volume of $50 \mu \mathrm{L}$ of complete growth medium and 100 $\mu \mathrm{L}$ of $1.2 \times 105$ cells $/ \mathrm{ml} \mathrm{HeLa}$ and NIH/3T3 cells were seeded into the 96-wells flat bottom microtiter plate (Nunclon, USA). The plate was then incubated for 24 hours. Four samples treatments of $100 \mu \mathrm{L}$ were added into wells in triplicate and serially diluted and then were incubated for 72 hours in $5 \% \mathrm{CO}_{2}$ incubator. After 72 hours, $20 \mu \mathrm{L}$ of 5 $\mathrm{mg} / \mathrm{mL}$ MTT solution was added into each well and incubated for 3 hours. The culture medium was removed from each well after 3 hours and $100 \mu \mathrm{L}$ of $100 \%$ DMSO were added to each well. The plate then was read by microplate reader at $570 \mathrm{~nm}$ with reference of $630 \mathrm{~nm}$ wavelength (BioTek, USA). The graph of percentage of cell viability versus concentration of sample treatment was plotted.

\section{RESULTS}

Isolation process of this study from Recycling Preparative HPLC method gave lignans of hypophyllanthin (1) from hexane crude while niranthin (2) and lintetralin (3) from ethanol crude. From the MTT assay results, hypophyllanthin possess an active cytotoxic activity towards HeLa cells compared to lintetralin and niranthin.
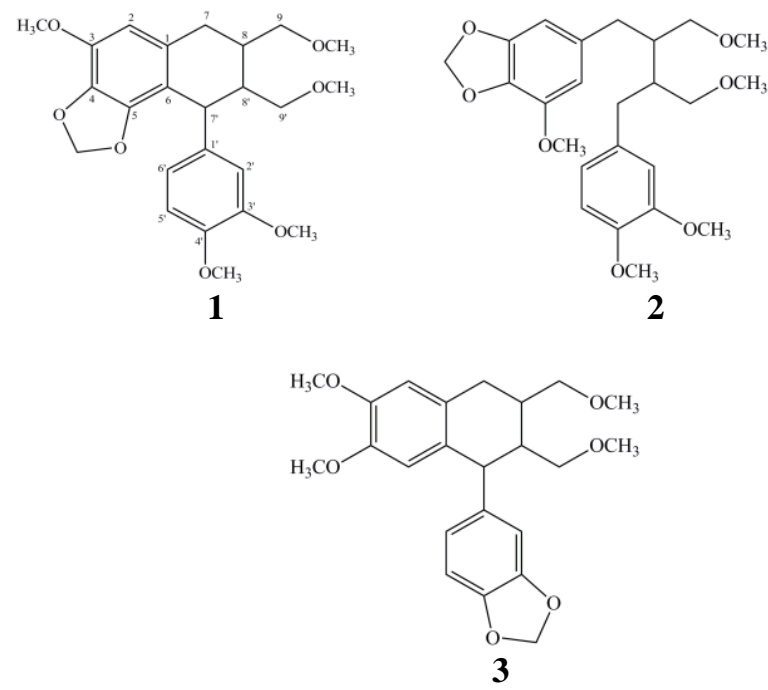

\section{A. Spectral Data of Isolated Compound}

Hypophyllanthin (1): 10.5mg (29.9\%). ${ }^{1} \mathrm{H}$ NMR $(500 \mathrm{MHz}$, $\left.\mathrm{CDCl}_{3}\right), \delta: 6.33(1 \mathrm{H}, s, \mathrm{H}-2), 3.87\left(3 \mathrm{H}, s, 3-\mathrm{OCH}_{3}\right), 5.73(2 \mathrm{H}$, $\left.d, J=1.70 \mathrm{~Hz}, \mathrm{O}-\mathrm{CH}_{2}-\mathrm{O}\right), 5.65\left(2 \mathrm{H}, d, J=1.75 \mathrm{~Hz},-\mathrm{OCH}_{2} \mathrm{O}-\right)$, $2.80(2 \mathrm{H}, d d, J=4.55 \mathrm{~Hz}, 15.45 \mathrm{~Hz}, \mathrm{H}-7), 2.76(2 \mathrm{H}, t$, $J=10.85 \mathrm{~Hz}, \mathrm{H}-7), 1.98(1 \mathrm{H}, m, \mathrm{H}-8), 3.42(2 \mathrm{H}, d d, J=4.00$ $\mathrm{Hz}, 9.15 \mathrm{~Hz}, \mathrm{H}-9), 3.36(2 \mathrm{H}, m, \mathrm{H}-9), 3.31\left(3 \mathrm{H}, s, 9-\mathrm{OCH}_{3}\right)$, $6.74\left(1 \mathrm{H}, d, J=8.60 \mathrm{~Hz}, \mathrm{H}-2^{\prime}\right), 3.80\left(3 \mathrm{H}, s, 3^{\prime}-\mathrm{OCH}_{3}\right), 3.85$ $\left(3 \mathrm{H}, s, 4^{\prime}-\mathrm{OCH}_{3}\right), 6.64\left(1 \mathrm{H}, d d, J=1.70 \mathrm{~Hz}, 8.00 \mathrm{~Hz}, \mathrm{H}-5^{\prime}\right)$, $6.66\left(1 \mathrm{H}, d, J=1.75 \mathrm{~Hz}, \mathrm{H}-6^{\prime}\right), 4.09\left(1 \mathrm{H}, d, J=8.05 \mathrm{~Hz}, \mathrm{H}-7^{\prime}\right)$, $1.89\left(1 \mathrm{H}, m, \mathrm{H}-8^{\prime}\right), 3.33\left(2 \mathrm{H}, s, \mathrm{H}-9^{\prime}\right), 3.24(2 \mathrm{H}, d d, J=3.40$ $\left.\mathrm{Hz}, 9.15 \mathrm{~Hz}, \mathrm{H}-9^{\prime}\right), 3.29\left(3 \mathrm{H}, s, 9{ }^{\prime}-\mathrm{OCH}_{3}\right) .{ }^{13} \mathrm{C}$ NMR $(125$ $\mathrm{MHz}, \mathrm{CDCl}_{3}$ ), $\delta: 131.8$ (C-1), 106.4 (C-2), 142.1 (C-3), 55.9 $\left(3-\mathrm{OCH}_{3}\right), 133.3(\mathrm{C}-4), 101.2\left(-\mathrm{OCH}_{2} \mathrm{O}-\right), 147.1(\mathrm{C}-5), 115.1$ (C-6), 33.4 (C-7), 36.7 (C-8), $75.5(\mathrm{C}-9), 59.0\left(9-\mathrm{OCH}_{3}\right)$, $138.0\left(\mathrm{C}-1^{\prime}\right), 110.6\left(\mathrm{C}-2^{\prime}\right), 148.5\left(\mathrm{C}-3^{\prime}\right), 55.8\left(3^{\prime}-\mathrm{OCH}_{3}\right)$, $147.1\left(\mathrm{C}^{4} 4^{\prime}\right), 56.4\left(4^{\prime}-\mathrm{OCH}_{3}\right), 120.5\left(\mathrm{C}-5^{\prime}\right), 111.7\left(\mathrm{C}^{\prime}-6^{\prime}\right), 42.0$ (C-7'), $45.5\left(\mathrm{C}-8^{\prime}\right), 71.7\left(\mathrm{C}-9^{\prime}\right), 59.0\left(9^{\prime}-\mathrm{OCH}_{3}\right)$.

Niranthin (2): 5.6mg (30.8\%). ${ }^{1} \mathrm{H}$ NMR (500 MHz, $\mathrm{CDCl}_{3}$ ), $\delta: 6.30(1 \mathrm{H}, d, J=1.15 \mathrm{~Hz}, \mathrm{H}-2), 5.93\left(2 \mathrm{H}, s,-\mathrm{OCH}_{2} \mathrm{O}-\right), 3.83$ $\left(3 \mathrm{H}, s, 5-\mathrm{OCH}_{3}\right), 6.25(1 \mathrm{H}, d, J=1.15 \mathrm{~Hz} . \mathrm{H}-6), 2.59(2 \mathrm{H}, t$, $J=5.15, \mathrm{H}-7), 2.63(2 \mathrm{H}, t, J=8.05, \mathrm{H}-7), 2.02(1 \mathrm{H}, m, \mathrm{H}-8)$, $3.30(2 \mathrm{H}, s, \mathrm{H}-9), 3.30\left(3 \mathrm{H}, s, 9-\mathrm{OCH}_{3}\right), 6.62(1 \mathrm{H}, d, J=1.70$ $\mathrm{Hz}, \mathrm{H}-2$ '), $3.86\left(3 \mathrm{H}, s, 3^{\prime}-\mathrm{OCH}_{3}\right), 3.82\left(3 \mathrm{H}, s, 4^{\prime}-\mathrm{OCH}_{3}\right), 6.76$ $\left(1 \mathrm{H}, d, J=8.00 \mathrm{~Hz}, \mathrm{H}-5^{\prime}\right), 6.65(1 \mathrm{H}, d d, J=2.30 \mathrm{~Hz}, 8.05 \mathrm{~Hz}$, H-6'), $2.66\left(2 \mathrm{H}, d d, J=2.85 \mathrm{~Hz}, 6.85 \mathrm{~Hz}, \mathrm{H}-7^{\prime}\right), 2.67(2 \mathrm{H}, t$, $\left.J=6.90 \mathrm{~Hz}, \mathrm{H}-7^{\prime}\right), 2.02(1 \mathrm{H}, m$, H-8'), 3.30 (2H, $\left.s, \mathrm{H}^{-} 9^{\prime}\right), 3.30$ $\left(3 \mathrm{H}, s, 9{ }^{\prime}-\mathrm{OCH}_{3}\right) .{ }^{13} \mathrm{C}$ NMR 
(125 MHz, $\left.\mathrm{CDCl}_{3}\right), \delta: 135.7(\mathrm{C}-1), 103.2(\mathrm{C}-2), 148.6(\mathrm{C}-3)$, 133.6 (C-4), 101.3 (-OCH $2 \mathrm{O}-), 143.4$ (C-5) $56.5\left(5-\mathrm{OCH}_{3}\right)$, 108.0 (C-6), 35.5(C-7), 40.9 (C-8), 72.6 (C-9), 59.0 $\left.\left(9-\mathrm{OCH}_{3} \mathrm{O}\right), 133.2\left(\mathrm{C}-1^{\prime}\right), 112.1\left(\mathrm{C}^{2}\right)^{\prime}\right), 147.1\left(\mathrm{C}^{\prime} 3^{\prime}\right), 55.9$ $\left(3^{\prime}-\mathrm{OCH}_{3}\right), 148.7\left(\mathrm{C}^{\prime} 4^{\prime}\right), 55.8\left(4^{\prime}-\mathrm{OCH}_{3}\right), 110.9\left(\mathrm{C}-5^{\prime}\right), 121.1$ (C-6'), 35.0 (C-7'), 40.8 (C-8'), 72.5 (C-9'), $58.9\left(9^{\prime}-\mathrm{OCH}_{3}\right)$.

Lintetralin (3): 3.0mg (9.4\%). ${ }^{1} \mathrm{H} \mathrm{NMR}\left(500 \mathrm{MHz}, \mathrm{CDCl}_{3}\right)$, $\delta: 6.59(1 \mathrm{H}, s, \mathrm{H}-2), 3.61\left(3 \mathrm{H}, s, 3-\mathrm{OCH}_{3}\right), 3.84(1 \mathrm{H}, m$, $\left.4-\mathrm{OCH}_{3}\right), 5.94\left(2 \mathrm{H}, d, J=4.00 \mathrm{~Hz},-\mathrm{OCH}_{2} \mathrm{O}-\right), 6.23(1 \mathrm{H}, s$, $\mathrm{H}-5), 2.82(2 \mathrm{H}, d, J=8.05 \mathrm{~Hz}, \mathrm{H}-7), 2.14(1 \mathrm{H}, m, \mathrm{H}-8), 3.48$ $(2 \mathrm{H}, d d, J=2.90,9.20 \mathrm{~Hz}, \mathrm{H}-9), 3.43(2 \mathrm{H}, d d, J=6.30,9.15$ $\mathrm{Hz}, \mathrm{H}-9), 3.36\left(3 \mathrm{H}, s, 9-\mathrm{OCH}_{3}\right), 6.57(1 \mathrm{H}, d, J=1.75 \mathrm{~Hz}$, H-2'), $6.74\left(1 \mathrm{H}, d, J=8.00 \mathrm{~Hz}, \mathrm{H}-5{ }^{\prime}\right), 6.64(1 \mathrm{H}, d d, J=1.75$, $\left.8.05 \mathrm{~Hz}, \mathrm{H}-6^{\prime}\right), 3.99$ (1H, $\left.d, J=10.35 \mathrm{~Hz}, \mathrm{H}-7^{\prime}\right), 1.79$ (1H, $m$, H-8'), 3.38 (2H, $\left.\left.d, J=2.85 \mathrm{~Hz}, \mathrm{H}^{-9}\right)^{\prime}\right), 3.11(2 \mathrm{H}, d d, J=3.40$, $9.70 \mathrm{~Hz}, \mathrm{H}-9$ '), 3.27 (3H, s, 9'-OCH $).{ }^{13} \mathrm{C} \mathrm{NMR}(500 \mathrm{MHz}$, $\left.\mathrm{CDCl}_{3}\right), \delta: 129.0(\mathrm{C}-1), 111.0(\mathrm{C}-2), 147.0(\mathrm{C}-3), 55.8$ $\left(3-\mathrm{OCH}_{3}\right), 147.1(\mathrm{C}-4), 55.9\left(4-\mathrm{OCH}_{3}\right), 100.9\left(-\mathrm{OCH}_{2} \mathrm{O}-\right)$, 112.8 (C-5), 131.9 (C-6), 33.3 (C-7), 36.3 (C-8), 75.3 (C-9), $59.1\left(9-\mathrm{OCH}_{3}\right), 139.8\left(\mathrm{C}-1^{\prime}\right), 109.4\left(\mathrm{C}-2^{\prime}\right), 147.7\left(\mathrm{C}-3^{\prime}\right)$, 145.9 (C-4'), 107.9 (C-5'), 122.8 (C-6'), 47.3 (C-7'), 45.1 (C-8'), $71.1\left(\mathrm{C}-9\right.$ '), $59.0\left(9^{\prime}-\mathrm{OCH}_{3}\right)$.

\section{DISCUSSION}

Hypophyllanthin (1) was isolated as white amorphous. The UV spectrum showed maxima absorption at $280 \mathrm{~nm}$ while the IR spectrum showed absorption at $1591 \mathrm{~cm}^{-1}$ for $\mathrm{C}=\mathrm{C}$ of aromatic ring groups. The molecular formula of this compound 1 was $\mathrm{C}_{24} \mathrm{H}_{30} \mathrm{O}_{7}$ correspond with protonated ion peak spectrum $430.10\left[\mathrm{M}^{+}\right]$.

The ${ }^{1} \mathrm{H}$ NMR spectrum of $\mathbf{1}$ showed one singlet signals in the aromatic region at $\delta 6.33$ which assigned for $\mathrm{C}-2$. Aromatic protons were showed by two doublet signals at $\delta$ $6.74(d, J=8.60 \mathrm{~Hz}), \delta 6.66(d, J=1.75 \mathrm{~Hz})$ and a doublet of doublet signals at $\delta 6.64(d d, J=1.70 \mathrm{~Hz}$ and $8.00 \mathrm{~Hz})$ which corresponding to proton at position H-2', H-6', and H-5', respectively. Another five singlet signals which belongs to five methoxy protons appeared at $\delta 3.87, \delta 3.80, \delta 3.85, \delta$ 3.31 and $\delta 3.29$ were attached to C-3, C-3', C-4', C-9 and C-9', respectively. Peak of methylenedioxy proton were showed as doublet signal at $\delta 5.73(d, J=1.70 \mathrm{~Hz})$ and $\delta 5.65$ $(d, J=1.75 \mathrm{~Hz})$. Besides that, the methylene protons were showed by signal of $\delta 2.80(d d, J=4.55 \mathrm{~Hz}$ and $15.45 \mathrm{~Hz})$ and $\delta 2.76(t, J=10.85 \mathrm{~Hz})$ at position $\mathrm{H}-7, \delta 3.42(d d, J=4.00 \mathrm{~Hz}$ and $9.15 \mathrm{~Hz}$ ) and multiplet signal at $\delta 3.36$ at position $\mathrm{H}-9$ while singlet signals at $\delta 3.33$ and $3.24(d d, J=3.40 \mathrm{~Hz}$ and $9.15 \mathrm{~Hz}$ ) were corresponding to H-9'.

The ${ }^{13} \mathrm{C}$ NMR spectrum of $\mathbf{1}$ showed a total of 24 carbon atoms. Among the 24 carbons, there were eight quaternary carbons: $\delta 131.8(\mathrm{C}-1), \delta 142.1$ (C-3), $\delta 133.3$ (C-4), $\delta 147.1$ (C-5), $\delta 115.1$ (C-6), $\delta 138.0\left(\mathrm{C}-1^{\prime}\right), \delta 148.5$ (C-3'), $\delta 147.1$ (C-4'); seven methine carbons: $\delta 106.4$ (C-2), $\delta 36.7$ (C-8), $\delta$ 110.6 (C-2'), $\delta 120.5$ (C-5'), $\delta 111.7$ (C-6'), $\delta 42.0$ (C-7'), $\delta$ $45.5\left(\mathrm{C}-8^{\prime}\right)$; five methoxy carbons: $\delta 55.9$ (3-OCH3), $\delta 59.0$ $\left(9-\mathrm{OCH}_{3}\right), \delta 55.8\left(3^{\prime}-\mathrm{OCH}_{3}\right), \delta 56.4\left(4^{\prime}-\mathrm{OCH}_{3}\right), \delta 59.0$ $\left(9 '-\mathrm{OCH}_{3}\right)$; and three methylene carbons: $\delta 33.4(\mathrm{C}-7), \delta 75.5$ (C-9), $\delta 71.7$ (C-9'). In addition, one methylenedioxy carbon signal at $\delta 101.2$ was also observed.
The position of these carbon resonances were further supported by ${ }^{1} \mathrm{H}-{ }^{1} \mathrm{H}$ COSY which provided the proton-proton coupling relations between $\mathrm{H} 7-\mathrm{H} 8, \mathrm{H} 8-\mathrm{H} 9$ and $\mathrm{H} 7{ }^{\prime}-\mathrm{H} 8$ '. Further correlation signals in the HMBC spectrum essential for elucidation of the structure of $\mathbf{1}$ were observed for $\mathrm{H}-2$ to C-3, C-4, C-6 and C-7; H-7 to C-1, C-2, C-6, C-8, C-8' and C-9; H-9 to C-8 and C-8'; H-2' to C-1' and C-3'; H-5' to C-4' and C-6'; and H-6' to C-1', C-4' and C-7'.

The complete assignments for the proton and carbon signals shown have confirmed the compound $\mathbf{1}$ as hypophyllanthin as all its NMR data were identical to those reported in the literature for hypophyllanthin [25].

Compound 2 was obtained as a brownish amorphous. The UV spectrum showed absorbance band at $280 \mathrm{~nm}$. The IR spectrum showed absorption at $16591 \mathrm{~cm}^{-1}$ for $\mathrm{C}=\mathrm{C}$ of aromatic ring groups. The molecular formula of $\mathbf{2}$ was $\mathrm{C}_{24} \mathrm{H}_{31} \mathrm{O}_{7}$. The mass spectrum revealed a protonated molecule ion peak at $432.21\left[\mathrm{M}^{+}\right]$. This compound was isolated from ethanol crude using $100 \%$ of acetonitrile by Recycling Preparative HPLC.

The ${ }^{1} \mathrm{H}$ NMR spectrum of compound 2 showed aromatic hydrogen region of $\delta 6.25(d, J=1.15 \mathrm{~Hz}), 6.30(d, J=1.15$ $\mathrm{Hz}), 6.62(d, J=1.70 \mathrm{~Hz}), 6.65(d d, J=2.30 \mathrm{~Hz}, 8.05 \mathrm{~Hz})$ and $6.76(d, J=8.00 \mathrm{~Hz})$ that attached at H-6, H-2, H-2', H-6' and H-5', respectively. Singlet signal of $\delta 5.93$ showed the presence of methylenedioxy, $-\mathrm{OCH}_{2} \mathrm{O}$-. It have five methoxy groups which were singlet signals of $\delta 3.82,3.83$ and 3.86 attached at ${ }^{\prime}-\mathrm{OCH}_{3}, 5-\mathrm{OCH}_{3}$ and $3^{\prime}-\mathrm{OCH}_{3}$, respectively. Besides, this compound also has two methoxy groups bonded to the alkyl side chain which are singlet signals of $\delta 3.30$ at both $9-\mathrm{OCH}_{3}$ and 9 '- $\mathrm{OCH}_{3}$. Methine groups $(\mathrm{CH})$ were showed as multiplet signals at $\mathrm{H}-8$ and $\mathrm{H}-8^{\prime}(\delta$ 2.02). The methylene groups appeared at $\mathrm{H}-7$ as triplet signals of $\delta 2.59$ $(J=5.15 \mathrm{~Hz})$ and $\delta 2.63(J=8.05 \mathrm{~Hz}), \mathrm{H}-7^{\prime}$ appeared as doublet of doublet signal of $\delta 2.66(J=2.85 \mathrm{~Hz}, 6.85 \mathrm{~Hz})$ and triplet signal of $\delta 2.67(\mathrm{~J}=6.90 \mathrm{~Hz})$ whereas a singlet signals of $\delta 3.30$ appeared at $\mathrm{H}-9$ and $\mathrm{H}_{-} \mathbf{9}^{\prime}$. The COSY spectrum showed proton correlation between $\mathrm{H}-5^{\prime}$ with H-6' and $\mathrm{H}-\mathrm{7}^{\prime}$ with $\mathrm{H}-8^{\prime}$.

According to the ${ }^{13} \mathrm{C}$ and DEPT NMR spectrum, there were seven quarternary carbons that appeared at $\delta$ 133.2, 133.6, 135.7, 143.4, 147.1, 148.6 and 148.7 corresponding to C-1', C-4, C-1, C-5, C-3', C-3 and C-4'. Methylenedioxy carbon showed a signal at $\delta 101.3$ and methoxy group that attached to aromatic ring showed signals at $\delta 55.8,55.9$ and 56.5 corresponding to $4 '-\mathrm{OCH}_{3}, 3^{\prime}-\mathrm{OCH}_{3}$ and $5-\mathrm{OCH}_{3}$, respectively. Meanwhile, the methoxy carbon that attached to alkyl chain showed signals of $\delta 58.9\left(9 '-\mathrm{OCH}_{3}\right)$ and $\delta 59.0$ $\left(9-\mathrm{OCH}_{3}\right)$. The other signals were four methylene carbons of C-7', C-7, C-9' and C-9 at $\delta 35.0,35.5,72.5$ and 72.6 and two methine carbons of C-8' and C-8 at $\delta 40.8$ and 40.9 . The five aromatic carbons were showed at $\delta 103.2$ (C-2), $108.0(\mathrm{C}-6)$, 110.9 (C-5'), 112.1 (C-2') and 121.1 (C-6'). On the basis of spectral data analysis and by comparison of these assignments with those of structurally related, the chemical structure of compound wasdeduced as niranthin [24].

Analysis of ${ }^{1} \mathrm{H}$ and ${ }^{13} \mathrm{C}$ spectra along with COSY, 
HMQC and HMBC spectrum suggested that compound $\mathbf{3}$ was lintetralin which obtained as brownish oil with molecular formula $\mathrm{C}_{23} \mathrm{H}_{28} \mathrm{O}_{6}$. Mass spectrum revealed a protonated molecule ion peak at $400.19\left[\mathrm{M}^{+}\right]$and IR spectrum data suggested the following information for the structural elucidation of compound $\mathbf{3}$

was $1591 \mathrm{~cm}^{-1}$ indicate the $\mathrm{C}=\mathrm{C}$ for aromatic ring groups while the maximum absorption of UV spectrum was $282 \mathrm{~nm}$ for the aromatic ring groups.

The ${ }^{1} \mathrm{H}$ NMR spectrum showed four methoxyl proton at $\delta$ $3.61(s), 3.84(m), 3.36(s)$ and $3.27(s)$ which were assigned to proton at $3-\mathrm{OCH}_{3}, 4-\mathrm{OCH}_{3}, 9-\mathrm{OCH}_{3}$ and $9^{\prime}-\mathrm{OCH}_{3}$, respectively. There were also five aromatic proton signals at $\delta 6.59(s), 6.23(s), 6.57(d, J=1.75 \mathrm{~Hz}), 6.74(d, J=8.00 \mathrm{~Hz})$ and $6.64(d d, J=1.75$ and $8.05 \mathrm{~Hz})$ that belongs to proton at position $\mathrm{H}-2, \mathrm{H}-5, \mathrm{H}-2$ ', $\mathrm{H}-5^{\prime}$ and $\mathrm{H}-6$ ', respectively. The methylene proton at $\mathrm{H}-7$ was showed by doublet signals of $\delta$ $2.82(\mathrm{~J}=8.05 \mathrm{~Hz}), \mathrm{H}-9$ were showed by two doublet of doublet signals at $\delta 3.48(J=2.90$ and $9.20 \mathrm{~Hz})$ and $3.43(J=6.30$ and $9.15 \mathrm{~Hz})$ and at $\mathrm{H}-9$ ' also showed doublet signal at $\delta 3.38$ $(J=2.85 \mathrm{~Hz})$ and a doublet of doublet signals at $\delta 3.11$ $(J=3.40$ and 9.70). There were also three signals of methine protons at $\mathrm{H}-\mathrm{7}^{\prime}, \mathrm{H}-8$ and $\mathrm{H}-8^{\prime}$ of doublet signals at $\delta 3.99$ $(J=10.35 \mathrm{~Hz})$ and two multiplet signals at $\delta 2.14$ and $\delta 1.79$, respectively. Besides that, dioxycyclopentane proton showed doublet signals of $\delta 5.94$ with coupling of 4.00 .

The ${ }^{13} \mathrm{C}$ and DEPT NMR data of $\mathbf{3}$ showed the presence of 23 carbon with seven quaternary carbons; 129.0 (C-1), 147.0 (C-3), 147.1 (C-4), 131.9 (C-6), 139.8 (C-1'), 147.7 (C-3') and 145.9 (C-4'), 4 methylene carbons; 33.3 (C-7), 75.3 (C-9), 71.1 (C-9') and $100.9\left(-\mathrm{OCH}_{2} \mathrm{O}-\right)$, four methoxy carbons; $55.8\left(3-\mathrm{OCH}_{3}\right), 55.9\left(4-\mathrm{OCH}_{3}\right), 59.1\left(9-\mathrm{OCH}_{3}\right)$ and $59.0\left(9^{\prime}-\mathrm{OCH}_{3}\right)$ and eight methine carbons; $111.0(\mathrm{C}-2)$, 112.8 (C-5), 36.3 (C-8), 109.4 (C-2'), 107.9 (C-5'), 122.8 (C-6'), 47.3 (C-7') and $45.1\left(\mathrm{C}-8^{\prime}\right)$.

\section{A.Anticancer Activity of Isolated Compound}

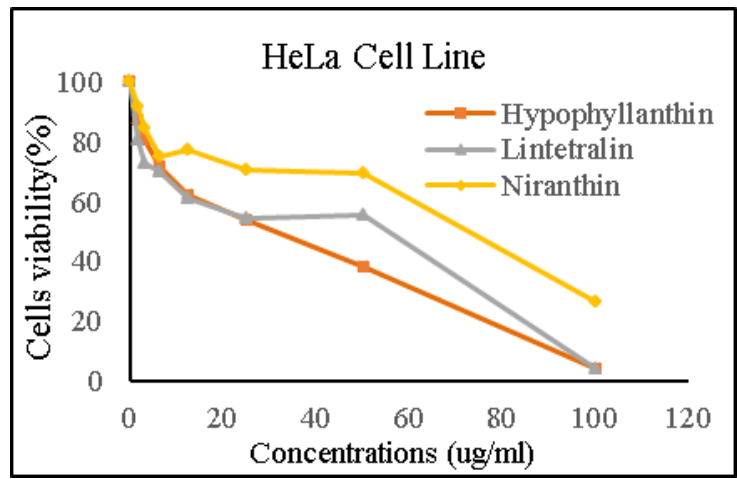

Fig. 1 Effects of Compounds on the Viability of HeLa cells

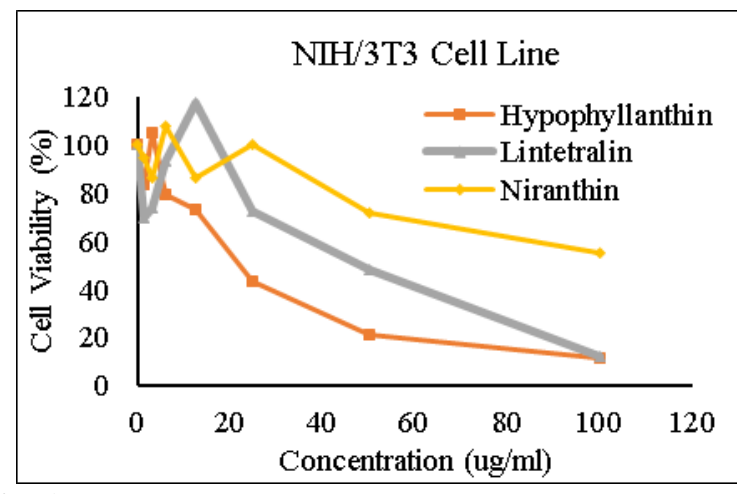

Fig. 2 Effects of Compounds on the Viability of NIH/3T3 cells

Hypophyllanthin, niranthin and lintetralin were tested for anticancer activity on human cervical cancer cell lines (HeLa) and normal mouse fibroblast cell lines (NIH/3T3) which evaluated by MTT assays. Those three compounds were tested with different concentration varying from 100 to $1.5625 \mu \mathrm{g} / \mathrm{mL}$. From the MTT assay results, hypophyllanthin decreased the HeLa cell population to $50 \%$ $\left(\mathrm{IC}_{50}\right)$ at $30.1 \mu \mathrm{g} / \mathrm{mL}$ compared to niranthin and lintetralin at $70.4 \mu \mathrm{g} / \mathrm{mL}$ and $50.5 \mu \mathrm{g} / \mathrm{mL}$, respectively as referred to Figure 1. However, the niranthin was inactive in cytotoxic activity towards normal mouse fibroblast cell line, NIH/3T3. Figure 2 showed no $\mathrm{IC}_{50}$ value when NIH/3T3 cells treated with niranthin. The cell viability of the cells was reduced to $75 \%$ only even when treated with $50 \mu \mathrm{g} / \mathrm{mL}$ and slightly reduced to about $60 \%$ when the concentration of niranthin was increased to $100 \mu \mathrm{g} / \mathrm{mL}$. Hypophyllanthin showed the lowest $\mathrm{IC}_{50}$ values of $20.2 \mu \mathrm{g} / \mathrm{mL}$ when tested on $\mathrm{NIH} / 3 \mathrm{~T} 3$ cell lines. The viable cells of NIH/3T3 cells were decreased to $50 \%\left(\mathrm{IC}_{50}\right)$ when treated with $50 \mu \mathrm{g} / \mathrm{mL}$ of lintetralin which means that lintetralin was moderately active in cytotoxic activity to the NIH/3T3 cell lines. However, this result was very important for further study on the isolation of cytotoxic compounds from this $P$. amarus.

\section{CONCLUSION}

This research work has identified the presence of hypophyllanthin (1), niranthin (2) and lintetralin (3) from Phyllanthus amarus. The result from MTT assay showed that hypophyllanthin has a strong anticancer effect on HeLa cells and has potential to be used in cancer treatment compared to niranthin and lintetralin. However, all these three compounds were also found to be less cytotoxic towards $\mathrm{NIH} / 3 \mathrm{~T} 3$ cells.

\section{ACKNOWLEDGMENT}

The author gratefully acknowledged the instrumentation facilities provided by Universiti Pendidikan Sultan Idris, Tanjong Malim, Perak, Malaysia and Universiti Sultan Zainal Abidin, Besut, Terengganu, Malaysia.

\section{REFERENCES}

1. T. O. Ajala, C. I. Igwilo, I. A. Oreagba, O. A. Odeku, "The antiplasmodial effect of the extracts and formulated capsules of Phyllanthus amarus on plasmodium yoelii infection in mice," Asian Pacific Journal of Tropical Medicine, vol. 4, 2011, pp. 283-287.

2. A. H. M. Mahbubur Rahman, M. Akter, "Taxonomy and medicinal uses of Euphorbiaceae (Spurge) 
family of Rajshahi, Bangladesh," Research in Plant Sciences, vol. 1, no. 3, 2013, pp. 74-80.

3. S. Prasad M, S. Joshi DSD, K. Narendra, K. Srinivas, S. Bai J, L. Chandana M, K. Satya A, "Phytochemical and pharmacological evaluation of Euphorbiaceae family plant leaves- Acalypha Indica L., Croton Bonplandianum Baill," Mintage Journal of Pharmaceutical \& Medical Science, vol. 4, no. 3, 2016, pp. 17-22.

4. A. K. Tripathi, R. K. Verma, A. K. Gupta, M. M. Gupta, S. P. S. Khanuja, "Quantitative determination of phyllanthin and hypophyllanthin in Phyllanthus species by high-performance thin layer chromatography, "Phytochemical Analysis, vol. 17, 2006, pp. 394-397.

5. A. Adewale Adeneye, A. Senebo Benebo, "Protective effect of the aqueous leaf and seed extract of Phyllanthus amarus on gentamicin and acetaminophen-induced nephrotoxic rats," Journal of Ethnopharmacology, vol. 118, 2008, pp. 318-323.

6. B. Joseph and S. Justin Raj, "A comparitive study on various properties of five medicinally important plants, "International Journal of Pharmacology, vol. 7, no. 2, 2011, pp. 206-211.

7. B. Joseph and S. Justin Raj, "An overview: pharmacognostic properties of Phyllanthus amarus Linn, "International Journal of Pharmacology, vol. 7, no. 1, 2011, pp. 40-45

8. S. Khatoon, "Macro-microscopy \& planar chromatography-important tools for quality control and identification of adulterants/substitutes of unani drugs," International Journal of Advances in Pharmacy Medicine and Bioallied Sciences, vol. 3, no. 1, 2015, pp. 58-64.

9. J. Ram Patel, P. Tripathi, V. Sharma, N. Singh Chauhan and V. Kumar Dixit, $\square$ Phyllanthus amarus: Ethnomedicinal uses, phytochemistry and pharmacology: A review, $\square$ Journal of Ethnopharmacology, vol. 138, no. 2, 2011, pp. 286-313.

10. S. Verma, H. Sharma and M. Garg, $\square$ Phyllanthus amarus : A review" Journal of Pharmacognosy and Phytochemistry, vol. 3, no. 2, 2014, pp $18-22$.

11. A. A. Adeneye, "The leaf and seed aqueous extract of Phyllanthus amarus improves insulin resistance diabetes in experimental animal studies," Journal of Ethnopharmacology, vol. 144, no 3, 2012, pp 705-711.

12. A. Islam, T. Selvan, U. K. Mazumder, M. Gupta and S. Ghosal, "Antitumour Effect of phyllanthin and hypophyllanthin from Phyllanthus amarus against ehrlich ascites carcinoma in mice," Pharmacologyonline, vol. 2, 2008, pp. 796-807.

13. A. D. Kandhare, P. Ghosh, A. E. Ghule, G. N. Zambare and S. L. Bodhankar, $\square$ Protective effect of Phyllanthus amarus by modulation of endogenous biomarkers and DNA damage in acetic acid induced ulcerative colitis : Role of phyllanthin and hypophyllanthin," Apollo Medicine, vol. 10, no. 1, 2013, pp. 8797.

14. C. A. L. Kassuya, A. A. Silvestre, V. L. G. Rehder and J. B. Calixto, "Anti-allodynic and anti-oedematogenic properties of the extract and lignans from Phyllanthus amarus in models of persistent inflammatory and neuropathic pain," European Journal of Pharmacology, vol. 478, 2003, pp. 145-153.

15. P. M. Kiran, and B. G. Rao, "Evaluation of anti-inflammatory activity of different extracts and isolated lignans of Phyllanthus amarus Schum. \& Thonn. aerial parts," International Journal of Pharma and Bio Sciences, vol. 4, no. 2, 2013, pp. 803-808.

16. B. Sarin, N. Verma, J. Pedro Martin and A. Mohanty, "An overview of important ethnomedicinal herbs of Phyllanthus species: Present status and future prospects," The Scientific World Journal, 2014, pp. 1-12.

17. U. T. Mamza, O. A. Sodipo and I. Z. Khan, "Gas chromatography-mass spectrometry: Analysis of bioactive components of Phyllanthus amarus leaves," International Research Journal of Plant Science, vol. 3, no. 10, 2012, pp. 208-215.

18. G. Abhyankar, K. V. Rao and V. D. Reddy, "Genomic and metabolomic fingerprinting of Phyllanthus amarus (Schumm \& Thonn) hairy root clones," Annals of Phytomedicine, vol. 2, no. 1, 2013, pp. 74-88.

19. G. Abhyankar, P. Suprasanna, B. N. Pandey, K. P. Mishra, K. V. Rao and V. D. Reddy, "Hairy root extract of Phyllanthus amarus induces apoptotic cell death in human breast cancer cells," Innovative Food Science and Emerging Technologies, vol. 11, no. 3, 2010, pp. 526-532.

20. R. Krithika, R. J. Verma, P. S. Shrivastav and L. Suguna, "Phyllanthin of standardized Phyllanthus amarus extract attenuates liver oxidative stress in mice and exerts cytoprotective activity on human hepatoma cell line," Journal of Clinical and Experimental Hepatology, vol. 1, no. 2, 2011, pp 57-67.

21. B. Sparzak, M. Krauze-Baranowska, A. Kawiak, P. Sowinski, "Cytotoxic lignan from the non-transformed root culture of Phyllanthus amarus," Molecules, vol. 20, no. 5, 2015, pp. 7915-7924.
22. J. S. Thakur, R. K. Agarwal and M. D. Kharya, "Immobilization mediated enhancement of phyllanthin and hypophyllanthin from Phyllanthus amarus," Chinese Journal of Natural Medicines, vol. 10, no. 3, 2012, pp. 207-212.

23. N. P. Yadav, A. Pal, K. Shanker, D. U. Bawankule, A. K. Gupta, M. P. Darokar and S. P. S. Khanuja, "Synergistic effect of silymarin and standardized extract of Phyllanthus amarus against $\mathrm{CCl} 4$-induced hepatotoxicity in Rattus norvegicus," Journal of Phytomedicine, vol. 15, 2008, pp. 1053-1061.

24. S. Liu, W. Wei, K. Shi, X. Cao, M. Zhou, Z. Liu, "In vitro and in vivo anti-hepatitis B virus activities of the lignan niranthin isolated from Phyllanthus niruri L.," Journal of Ehnopharmacology, vol. 155, no. 2, 2014, pp. 1061-1067.

25. M. A. M. Maciel, A. F. Cunha and T. N. C. Dantas, "NMR characterization of bioactive lignans from Phyllanthus amarus Schum \& Thorn., Annals of Magnetic Resonance, vol. 6, no. 3, 2007, pp. 76-82. 